\title{
Normal complete blood count reference intervals in the Turkish population: a prospective study
}

\begin{abstract}
This study aim to analyze and report the normal complete blood count $(\mathrm{CBC})$ reference intervals in the Turkish population. 1375 healthy people living in Manisa-Turkey, nonpregnant, with no known disease, with no pathological entity in physical examination and anamnesis, with no medicine usage in the last 15 days, stating that they and also their first degree relatives do not have any blood diseases, were included in the study. Vitamin B12, folic acid, ferritin levels were analyzed for each of the participants. CBC values of the remaining 714 people, of which 363 were women and 351 were men, were studied. Platelet (PLT), Plateletcrit (PCT), Red cell Distribution Width (RDW) levels and the neutrophil ratio were found significantly higher in females. On the other hand hemoglobin ( $\mathrm{Hb})$, Total Red Blood Cell count (RBC),Hematocrit (Hct), mean cellular volume (MCV), mean cellular hemoglobin $(\mathrm{MCH})$, mean corpuscular hemoglobin concentration (MCHC) levels together with monocyte count and ratio were found significantly higher in males $(\mathrm{p}<0.05)$. World Health Organization (WHO) defines anemia as the level of $\mathrm{Hb}$ being less than $13 \mathrm{~g} / \mathrm{dL}$ for men. In our study we found this level to be $15,39 \pm 1,067(14) \mathrm{gr} / \mathrm{dL}$. WHO defines anemia as the level of $\mathrm{Hb}$ less than $12 \mathrm{~g} / \mathrm{dL}$ for women. In our study we found this level to be $13,26 \pm 1,068(12) \mathrm{gr} /$ $\mathrm{dL}$. We found that anemia borderline of the women in our region was consistent with anemia borderline of WHO.
\end{abstract}

Keywords: anemia, turkey, hemoglobins, plateletcrit, platelet, vitamin
Volume 6 Issue 4 - 2018

\author{
Emine Aygör Kabasakal,' Ülkü Ergene, ${ }^{2}$ Can \\ Özlü̉ \\ 'Department of Internal Medicine, Celal Bayar Univercity, Turkey \\ ${ }^{2}$ Department of Hematology, Sağlik BilimLeri Univercity Bozyaka \\ Hospital,Turkey \\ ${ }^{3}$ Department of Hematology, Sağlik BilimLeri Univercity \\ Erzurum State Education and Research Hospital,Turkey
}

Correspondence: Can Özlü, Department of Hematology Sağlik BilimLeri Univercity, Bozyaka Hospital, Hematology, Izmir, Turkey, Fax +90232 25050 50, Tel +90 50547918 72, Email cozlu20@gmail.com

Received: June 04, 2018 | Published: July 26, 2018
Abbreviations $\mathrm{CBC}$, complete blood count; RDW, red cell distribution width; RBC, red blood cell count; Hct, Hematocrit; MCV, mean cellular volume; $\mathrm{MCH}$, mean cellular hemoglobin; MCHC, mean corpuscular hemoglobin concentration

\section{Introduction}

There are many elements affecting the normal CBC levels, and those levels change according to the race, sex, population and the district. Studies have been performed in order to establish the reference $\mathrm{CBC}$ levels in many regions. As the reference levels of those studies are different from each other, we have thought to have different results also in our country. The city of Manisa (number of population in 2015: 1.380.366) is developed in terms of agriculture and industry, and allows high numbers of immigrants from other regions of Turkey (the number of immigrants between 2007-2014: 236.535 according to the data of Turkish statistical institute). We thought that a study made in the city of Manisa can form an opinion for the CBC parameters of our country.

\section{Material and method}

\section{Study design}

We have included 1375 people totally in the study, between the dates November 2011 and January 2013. 562 of them were male and 813 were female. The participants were selected from healthy people with no known disease between the ages 18-70, who were not on continuous medical treatment, did not take any medications since the last 15 days, and were not known to have hereditary blood disease in their families, with normal physical examination. All of the participants were informed, and they signed the volunteer forms.

$2 \mathrm{~mL}$ of venous blood into Ethylene daimine tetraacetic acid (EDTA)-tube and $5 \mathrm{~mL}$ venous blood into serum tube were collected from all of the participants of the study, between 08:30 and 14:00. Those blood samples were examined within the first two hours after sample collection in the hospital laboratory. CBC and vitamin B12, folic acid, ferritin levels were analyzed for each of the participants. Since the deficiencies of vitamin B12, folic acid and/or ferritin are the most frequent reason of anemia in the population, we excluded the subjects with decreased levels of those from the study.

CBC parameters from the blood taken into EDTA-tubes were analyzed with Mindry BC-6800 device. Ferritin, vitamin B12 and folic acid levels were analyzed with DXI-800 Beckman Coulter brand device by using Beckman Coulter Syncron Systems kit.

\section{Statistical analysis}

Statistical analyses were performed by SPSS (Statistical Package for Social Sciences) for Windows 15.0.

\section{Results}

1375 people in total, from which 562 were male and 813 were female, participated in the study. Mean age of all participants was 29.61 \pm 8.6 . Mean age in women was $28.65 \pm 8.52$ (median: 27 ) and mean age in men was $30.99 \pm 8.53$ (median: 27 ). When we excluded people with deficiency of either vitamin B12 or folic acid or ferritin, 714 people was the total number of the participants, from which 363 were female and 351 were male (Table 1).

We have examined the individuals separately according to the age, sex, place of birth and menopausal status.

While PLT, PCT, RDW, neutrophils (\%) were higher in women with a statistically significant level; Hb, RBC, hematocrit, MCV, $\mathrm{MCH}, \mathrm{MCHC}$, monocyte percentage and number and eosinophile percentage and number were higher in men with a statistically significant level. No statistically significant difference was observed 
between men and women in other $\mathrm{CBC}$ parameters (Table 2) (Table $3)$.

No statistically significant difference was observed in $\mathrm{CBC}$ parameters between women who were born in Manisa and not born in Manisa. WBC, monocyte and neutrophil counts of men who were born in Manisa were higher with a statistically significant difference than those who were not (Table 2) (Table 3).

Table I Averages of Age According to Gender

\begin{tabular}{lllllll}
\hline & \multicolumn{2}{l}{ All Groups } & \multicolumn{4}{c}{ Normal B 1 2-Feritin-Folic Acid Group } \\
\cline { 2 - 7 } & Women Age & Men Age & Total & Women Age & Men Age & Total \\
\hline N & 813 & 562 & 1375 & 363 & 351 & 714 \\
Mean & 28,65 & 30,99 & 29,61 & 28,69 & 30,94 & 29,8 \\
Median & 27 & 30 & 28 & 26 & 30 & 28 \\
Std. Deviation & 8,526 & 8,537 & 8,605 & 9,241 & 8,705 & 9,045 \\
\hline
\end{tabular}

Table 2 Averages of Hemogram Value of 35I Men

\begin{tabular}{|c|c|c|c|c|c|c|c|c|c|c|c|}
\hline & RBC & $\mathrm{Hb}$ & Hct & PLT & РCT & MCV & MCH & MCHC & RDW & MPV & PDW \\
\hline$N$ & 351 & 351 & 351 & 351 & 351 & 351 & 351 & 351 & 351 & 351 & 351 \\
\hline Mean & 5,02 & 15,39 & 44,69 & 232 & 0,223 & 89,1 & 30,7 & 34,4 & 13,15 & 9,65 & 16,3 \\
\hline Median & 5 & 15,4 & 44,7 & 233 & 0,219 & 89,2 & 30,8 & 34,3 & 13 & 9,6 & 16,3 \\
\hline \multirow[t]{2}{*}{$\begin{array}{l}\text { Std. } \\
\text { Deviation }\end{array}$} & 0,408 & I,067 & 3,2 & 47,86 & 0,0442 & 4,88 & I,95 & I,063 & 0,907 & I,085 & 0,563 \\
\hline & WBC & $\begin{array}{l}\text { Neut- } \\
\text { rophil } \\
\text { (\%) }\end{array}$ & $\begin{array}{l}\text { Lymp- } \\
\text { hocyte } \\
\text { (\%) }\end{array}$ & $\begin{array}{l}\text { Mono- } \\
\text { cyte } \\
(\%)\end{array}$ & $\begin{array}{l}\text { Eosi- } \\
\text { nophil } \\
\text { (\%) }\end{array}$ & $\begin{array}{l}\text { Basophil } \\
\text { (\%) }\end{array}$ & $\begin{array}{l}\text { Neut- } \\
\text { rophil } \\
\text { Count }\end{array}$ & $\begin{array}{l}\text { Lymp- } \\
\text { hocyte } \\
\text { Count }\end{array}$ & $\begin{array}{l}\text { Monocyte } \\
\text { Count }\end{array}$ & $\begin{array}{l}\text { Eosinop- } \\
\text { hil Count }\end{array}$ & $\begin{array}{l}\text { Basophil } \\
\text { Count }\end{array}$ \\
\hline$N$ & 351 & 351 & 351 & 351 & 351 & 351 & 351 & 351 & 351 & 351 & 351 \\
\hline Mean & 7,794 & 58,6 & 30,12 & 7,86 & 2,5 & 0,8 & 4,603 & 2,303 & 0,632 & 0,19 & 0,056 \\
\hline Median & 7,6 & 59 & 30,4 & 6,9 & 2,1 & 0,4 & 4,4 & 2,2 & 0,5 & 0,17 & 0 \\
\hline $\begin{array}{l}\text { Std. } \\
\text { Deviation }\end{array}$ & I,723 & 10,15 & 7,15 & 4,96 & I,735 & 2,49 & I,476 & 0,647 & 0,568 & 0,146 & 0,2 \\
\hline
\end{tabular}

Table 3 Averages of Hemogram Value of 363 Women

\begin{tabular}{|c|c|c|c|c|c|c|c|c|c|c|c|}
\hline & RBC & $\mathrm{Hb}$ & Hct & PLT & РCT & MCV & $\mathrm{MCH}$ & MCHC & RDW & MPV & PDW \\
\hline$N$ & 363 & 363 & 363 & 363 & 363 & 363 & 363 & 363 & 363 & 363 & 363 \\
\hline Mean & 4,41 & 13,26 & 38,82 & 254 & 0,244 & 88,2 & 30,1 & 34,1 & $|3,4|$ & 9,74 & 16,3 \\
\hline Median & 4,39 & 13,2 & 38,8 & 247 & 0,239 & 88,8 & 30,2 & 34,2 & $13, \mid$ & 9,7 & 16,2 \\
\hline \multirow[t]{2}{*}{ Std. Deviation } & 0,369 & 1,068 & 3,08 & 56,12 & 0,0488 & 4,92 & 1,972 & 0,921 & $\mathrm{I}, 778$ & 1,235 & 0,552 \\
\hline & WBC & $\begin{array}{l}\text { Lymp- } \\
\text { hocyte } \\
\text { (\%) }\end{array}$ & $\begin{array}{l}\text { Neut- } \\
\text { rophil } \\
(\%)\end{array}$ & $\begin{array}{l}\text { Mono- } \\
\text { cyte } \\
(\%)\end{array}$ & $\begin{array}{l}\text { Eosi- } \\
\text { nophil } \\
(\%)\end{array}$ & $\begin{array}{l}\text { Ba- } \\
\text { sophil } \\
\text { (\%) }\end{array}$ & $\begin{array}{l}\text { Neut- } \\
\text { rophil } \\
\text { Count }\end{array}$ & $\begin{array}{l}\text { Lymp- } \\
\text { hocyte } \\
\text { Count }\end{array}$ & $\begin{array}{l}\text { Mono- } \\
\text { cyte } \\
\text { Count }\end{array}$ & $\begin{array}{l}\text { Eosi- } \\
\text { nophil } \\
\text { Count }\end{array}$ & $\begin{array}{l}\text { Basophil } \\
\text { Count }\end{array}$ \\
\hline$N$ & 363 & 363 & 363 & 363 & 363 & 363 & 363 & 363 & 363 & 363 & 363 \\
\hline Mean & 7.765 & 30,1 & 60,3 & 7 & 1,99 & 0,7 & 4.727 & 2.295 & 0.538 & 0.154 & 0.438 \\
\hline Median & 7.5 & 30,5 & 60 & 6,6 & $\mathrm{I}, 6$ & 0,5 & 4.4 & 2.2 & 0.5 & 0.1 & 0 \\
\hline Std. Deviation & 1.889 & 7,137 & 8,917 & 3,7 & 1,918 & $\mathrm{I}, 33$ & 1.555 & 0.6716 & 0.323 & 0.152 & 0.1048 \\
\hline
\end{tabular}

\section{Discussion}

There are many elements affecting the $\mathrm{CBC}$ reference intervals, and those levels change according to the race, sex, population and the district. That's why the reference intervals of the hematological parameters differ from population to population. ${ }^{1-5}$
There have not been enough prospective studies for the reference intervals and the evaluation of the $\mathrm{CBC}$ parameters in our country.

The importance of our study comes from its potential to provide reference levels of hematological parameters at Turkey. We have analyzed many hematological parameters prospectively, by working on many men and women. We have also tried to obtain information 
about Turkey's data by evaluating the individuals separately as Manisa-born and non Manisa-born.
Table $4 \& 5$, together with the $\mathrm{CBC}$ results of our study, presents the $\mathrm{CBC}$ results of the studies conveyed in Turkey. ${ }^{6-10}$ The most important feature of our study is its prospectively.

Table 4 Comparison of our Study Results With the Other Studies Conducted in our Country

\begin{tabular}{|c|c|c|c|c|c|c|c|c|}
\hline \multirow{2}{*}{$\begin{array}{l}\text { Hemogram } \\
\text { values }\end{array}$} & \multirow{2}{*}{$\begin{array}{l}\text { Terzioğlu' } \\
\text { Women- } \\
\text { Men }\end{array}$} & \multirow{2}{*}{$\begin{array}{l}\text { Bașak }^{7} \\
\text { Women- } \\
\text { Men }\end{array}$} & \multirow{2}{*}{$\begin{array}{l}\text { Kaya }^{8} \\
\text { Women- } \\
\text { Men } \\
(n=2 \mid 33)\end{array}$} & \multirow{2}{*}{$\begin{array}{l}\text { Dilek }^{9} \\
\text { Women- } \\
\text { Men } \\
(n=642)\end{array}$} & \multicolumn{2}{|l|}{ Yilmaz $^{10}$} & \multicolumn{2}{|c|}{ Our study results } \\
\hline & & & & & Women-Me & $n(n=530)$ & Women-M & en $(n=7 \mid 4)$ \\
\hline $\mathrm{RBC}\left(10^{12} / \mathrm{L}\right)$ & $\begin{array}{l}4.5 \pm 0.6 \\
5.2 \pm 0.7\end{array}$ & $\begin{array}{l}4.5 \pm 0.4 \\
5.2 \pm 0.3\end{array}$ & $\begin{array}{l}4.6 \pm 0.4 \\
5.1 \pm 0.4\end{array}$ & $\begin{array}{l}4.8 \pm 0.5- \\
5.3 \pm 0.6\end{array}$ & $4.66 \pm 0.02$ & $5.27 \pm 0.02$ & $\begin{array}{l}4,41 \pm 0,36 \\
5,02 \pm 0,4\end{array}$ & \\
\hline $\mathrm{Hb}(\mathrm{gr} / \mathrm{dL})$ & $\begin{array}{l}12.4 \pm 2.3 \\
14.6 \pm 2.1\end{array}$ & $\begin{array}{l}13.6 \pm 1.1 \\
15.3 \pm 0.9\end{array}$ & $\begin{array}{l}\mid 4.6 \pm 1.6 \\
|5.4 \pm| .3\end{array}$ & $\begin{array}{l}13.4 \pm 1.7- \\
15.3 \pm 1.7\end{array}$ & $13.53 \pm 0.09$ & $15.78 \pm 0.06$ & $13,26 \pm 1$ & $15,39 \pm 1$ \\
\hline Hct (\%) & $\begin{array}{l}39.6 \pm 5 \\
44.6 \pm 9.6\end{array}$ & $\begin{array}{l}40.5 \pm 3.3 \\
45.2 \pm 2.8\end{array}$ & $\begin{array}{l}42.9 \pm 4.6 \\
45 \pm 3.9\end{array}$ & $\begin{array}{l}41.4 \pm 4.9- \\
46.6 \pm 5.4\end{array}$ & $39.19 \pm 0.4$ & $45.28 \pm 0.3$ & $38,82 \pm 3,08$ & $44,69 \pm 3,2$ \\
\hline PLT $\left(10^{9} / \mathrm{L}\right)$ & & $\begin{array}{l}235 \pm 52 \\
218 \pm 46\end{array}$ & $\begin{array}{l}243 \pm 55 \\
235 \pm 52\end{array}$ & $\begin{array}{l}221 \pm 75- \\
197 \pm 75\end{array}$ & $\begin{array}{l}281.01 \pm 5.79 \\
248.60 \pm 2.8\end{array}$ & & $\begin{array}{l}254 \pm 56,12 \\
232,7 \pm 47,86\end{array}$ & \\
\hline РCT(\%) & & & & & & & $\begin{array}{l}0,244 \pm 0,04 \\
0,223 \pm 0,04\end{array}$ & \\
\hline $\operatorname{MCV}(f \mathrm{l})$ & $\begin{array}{l}88.7 \pm 4.8 \\
85.2 \pm 10\end{array}$ & $\begin{array}{l}87 \pm 4.5 \\
86 \pm 4.2\end{array}$ & $\begin{array}{l}86.7 \pm 4.6 \\
88.2 \pm 4\end{array}$ & $87 \pm 5-84 \pm 4$ & $\begin{array}{l}84.01 \pm 0.47 \\
85.07 \pm 0.25\end{array}$ & & $88,2 \pm 4,92$ & $89, I \pm 4,88$ \\
\hline $\mathrm{MCH}(\mathrm{pg})$ & & & & & $\begin{array}{l}28.86 \pm 0.24 \\
30.10 \pm 0.18\end{array}$ & & $30,1 \pm 1,97$ & $30,7 \pm 1,95$ \\
\hline $\mathrm{MCHC}(\mathrm{gr} / \mathrm{dL})$ & & & & & $\begin{array}{l}34.5 \pm 0.11 \\
35.14 \pm 0.05\end{array}$ & & $\begin{array}{l}34, I \pm 0,92 \\
\pm 1,06\end{array}$ & 34,4 \\
\hline RDW & & & & & & & $\begin{array}{l}13,4 \mid \pm 1,77 \\
13,15 \pm 0,9\end{array}$ & \\
\hline PDW & & & & & & & $16,3 \pm 0,55$ & $16,3 \pm 0,56$ \\
\hline MPV & & & & & $\begin{array}{l}9.08 \pm 0.32 \\
0.06\end{array}$ & $8.68 \pm$ & $9,74 \pm 1,23$ & $9,65 \pm 1,08$ \\
\hline
\end{tabular}

Table 5 Comparison of our Study Results with the Other Studies Conducted in Our Country

\begin{tabular}{|c|c|c|c|c|c|c|c|}
\hline \multirow{2}{*}{$\begin{array}{l}\text { Hemogram } \\
\text { values }\end{array}$} & \multirow{2}{*}{$\begin{array}{l}\text { Bașak }^{7} \\
\text { Women- } \\
\text { Men }\end{array}$} & \multirow{2}{*}{$\begin{array}{l}\text { Kaya }^{8} \\
\text { Women- } \\
\text { Men }\end{array}$} & \multirow{2}{*}{$\begin{array}{l}\text { Dilek }^{9} \\
\text { Women- } \\
\text { Men } \\
(n=642)\end{array}$} & \multicolumn{2}{|l|}{ Yilmaz $^{10}$} & \multicolumn{2}{|c|}{ Results of our study } \\
\hline & & & & \multicolumn{2}{|c|}{ Women-Men $(n=530)$} & \multicolumn{2}{|c|}{ Women-Men $(n=7 \mid 4)$} \\
\hline \multirow[t]{2}{*}{ Leukocyte Count $\times 10^{9} / \mathrm{L}$} & $6.8 \pm 1.4$ & $7.4 \pm 2$ & $7.0 \pm 1.9$ & $6.78 \pm 0.11$ & $7.44 \pm 0.09$ & $7.765 \pm 1.889$ & $7.794 \pm I .723$ \\
\hline & $7.2 \pm 1.5$ & $7.8 \pm 2$ & $7.4 \pm 2.2$ & & & & \\
\hline Lymphocyte(\%) & & & & $30.43 \pm 0.54$ & $31.74 \pm 0.39$ & $\begin{array}{l}30,10 \pm 7,1 \\
30,4 \pm 7,15\end{array}$ & \\
\hline Monocyte(\%) & & & & $6.48 \pm 0.13$ & $6.55 \pm 0.10$ & $\begin{array}{l}7,0 \pm 3,7 \\
7,86 \pm 4,96\end{array}$ & \\
\hline Eosinophil(\%) & & & & $2.59 \pm 0.12$ & $3.04 \pm 0.09$ & $1,99 \pm 1,91$ & $2,5 \pm 1,73$ \\
\hline Basophil(\%) & & & & $\begin{array}{l}0.55 \pm 0.06 \\
0.03\end{array}$ & $0.53 \pm$ & $0,7 \pm I, 33$ & $0,8 \pm 2,49$ \\
\hline Neutrophyl Count $\times 10^{9} / \mathrm{L}$ & & & & & & $4.727 \pm 1.555$ & $4.603 \pm 1.476$ \\
\hline Lymphocyte Count $\times 10^{9} / \mathrm{L}$ & & & & & & $2.295 \pm 0.67 \mid$ & $2.303 \pm 0.647$ \\
\hline Monocyte Count $\times 10^{9} / \mathrm{L}$ & & & & & & $0.538 \pm 0.323$ & $0.632 \pm 0.568$ \\
\hline Eosinophil Count $\times 10^{9} / \mathrm{L}$ & & & & & & $0.154 \pm 0.152$ & $0.19 \pm 0.146$ \\
\hline Basophyl Count $\times 10^{9} / \mathrm{L}$ & & & & & & $0.043 \pm 0.104$ & $0.056 \pm 0.20$ \\
\hline
\end{tabular}


Average RBC values of our study, obtained from 714 individuals between the ages 18-70 are compatible with the studies of Y1lmaz et al., ${ }^{10}$ and Tamer et al. ${ }^{11}$ But the average value obtained from our study is lower than theirs. Castro et al., ${ }^{12}$ stated that RBC values at black individuals were lower than white ones, and this may be the result of the high incidence of thalassemia and iron deficiency anemia at black population. Sirdah et al. ${ }^{13}$ made a study between the years 2000- 2008 and 94.811 people were included in the study. But enough information was not given about the selection of healthy individuals and the ones with low levels of ferritin were included in the study. ${ }^{10-13}$

Roshan et al., ${ }^{14}$ gave $\mathrm{Hb}$ values as $11.83 \pm 1.01$ in women and $14.271 \pm 1.13$ in men. When compared with the result of our study, their average $\mathrm{Hb}$ values and reference intervals were lower both in men and women. We assume that the difference in $\mathrm{Hb}$ values between the results of Roshan et al., ${ }^{14}$ and us is due to the differences in geographical location, health, nutrition, gender and smoking status. Besides Roshans et al., ${ }^{14}$ did not exclude the individuals with vitamin B12, folic acid and iron deficiencies from their study, which are actually the most common causes of anemia in the world. ${ }^{14}$

Sirdah et al., ${ }^{13}$ found $\mathrm{Hb}$ values as $15.09 \pm 1,09$ in smoking men, $14,74 \pm 1,09$ in non-smoking men and $12,36 \pm 1,18 \mathrm{gr} / \mathrm{dL}$ in nonsmoking women. Sirdah et al., ${ }^{13}$ found that $\mathrm{Hb}$ values of non smokers are higher than the $\mathrm{Hb}$ values of smokers with a statistically significant difference. ${ }^{13}$ While WHO accepts the value under $13 \mathrm{gr} / \mathrm{dL}$ as anemia in men, we have obtained this value to be $15,39 \pm 1,067 \mathrm{gr} / \mathrm{dL}$ in our study $(14 \mathrm{gr} / \mathrm{dl})$. WHO accepts $\mathrm{Hb}$ value under $12 \mathrm{gr} / \mathrm{dL}$ as anemia in women, we have obtained this value to be less than $13,26 \pm 1,068(12)$ $\mathrm{gr} / \mathrm{dL}$, which is compatible with the result of WHO.

In our study, the average of the Hct values obtained from all of the participants aging between 18-70 were compatible with the studies of Tuncer et al., ${ }^{15}$ Tikly et al., ${ }^{16}$ Kelly \& Munan. ${ }^{17}$

Platelet values in women were found to be significantly higher than the values in men $(p=0,012)$ in our study. Although our normal values were compatible with the values of Tamer et al., ${ }^{11}$ and Tuncer et al., ${ }^{15}$ our average value was higher than Tamer et al.," ${ }^{11}$ average value. ${ }^{11,15}$ Researchers stated that platelet numbers were higher in women than men. This difference becomes clearer in the premenopausal period. Our study was also compatible with these results. In addition, we have found the number of platelet to be higher in women in menopause than women not in menopause.

When it comes to the comparison of average WBC values, Tikly et al., ${ }^{16}$ stated that the number of WBC count was lower in black individuals than white ones, and they also stated that the reason of that difference was not obvious. Kueviakoe et al., ${ }^{18}$ did not find statistically significant difference in WBC values between men and women. Sirdah et al., ${ }^{13}$ found that while WBC values of nonsmoking women were significantly higher than the values of nonsmoking men, it was also significantly higher in smoking men than in nonsmoking men $(\mathrm{p}<0,001)$. We didn't evaluate the individuals separately as smoker or nonsmoker in our study. ${ }^{16,18,13}$

Although there are some studies stating that WBC numbers are decreasing with the rise in altitude, there are also other studies that don't support this view. Rana et al., ${ }^{19}$ found WBC numbers higher in the adults of black race. The reason of this is attributed to nonexclusion of the pregnant women from the participants. ${ }^{19} \mathrm{We}$ have not included the pregnant women in our study, so the limits of our normal value seems to be higher than the results of those studies. We have also compared the WBC values between men and women and we saw that WBC values were higher in women. But we did not observe a statistically significant difference in WBC values between the women in menopause and not in menopause.

The averages of leukocyte, PLT, RBC- Hemoglobin-HematocritMCV-MCHC values in different ethnicities and \%90 confidence interval of these values were shown together with our results in Table $6 \& 7.2,18,20$ It is seen that WBC, \% neutrophil, \% lymphocyte, \% monocytes, \% eosinophile and platelet numbers are found higher in our study than the studies conducted on other ethnicities.

Consequently, with this prospective study, we have obtained data about normal CBC reference intervals in our region and in Turkish population by evaluation of 714 healthy participants with normal vitamin B12, folic acid and ferritin levels.

The most statistically significant result of this study is that, while WHO accepts values under $13 \mathrm{gr} / \mathrm{dL}$ as anemia for men, we have found this value to be $15,39 \pm 1,06(14) \mathrm{gr} / \mathrm{dL}$ in our study. WHO accepts values under $12 \mathrm{gr} / \mathrm{dL}$ as anemia in women, and we have found this value to be $13,26 \pm 1,068(12) \mathrm{gr} / \mathrm{dL}$ in our study. So our results are compatible with WHO's data. Performing studies with larger number of healthy volunteers who live in different regions will be more useful.

Table 6 Leucocyte-platelet count $\left(\times 10^{9} / \mathrm{L}\right)$ and percentile intervals(\%5-95) in different ethnicities

\begin{tabular}{|c|c|c|c|c|c|c|c|c|}
\hline \multirow[b]{2}{*}{$\begin{array}{l}\text { CBC Reference } \\
\text { Intervals }\end{array}$} & \multicolumn{4}{|l|}{ Men } & \multicolumn{4}{|l|}{ Women } \\
\hline & Caucasian & $\begin{array}{l}\text { Afro- } \\
\text { Caribbean }\end{array}$ & African & $\begin{array}{l}\text { Results of our } \\
\text { study }\end{array}$ & European & $\begin{array}{l}\text { Afro- } \\
\text { Caribbean }\end{array}$ & African & $\begin{array}{l}\text { Results } \\
\text { of our } \\
\text { study }\end{array}$ \\
\hline Number & $\mathrm{n}=100$ & $n=51$ & $n=65$ & $n=351$ & $\mathrm{n}=100$ & $n=5 I$ & $\mathrm{n}=50$ & $\mathrm{n}=363$ \\
\hline Leukocyte (x109/L) & 5.7 & 5.2 & 4.5 & 7.79 & 6.2 & 5.7 & 5 & 7.7 \\
\hline$\% 90 \mathrm{Cl}$ & $(3.6-9.2)$ & $(2.8-9.5)$ & $(2.8-7.2)$ & $(5.4-10.6)$ & $(3.5-10.8)$ & $(3.3-9.9)$ & $(3.2-7.8)$ & $(5 . I-I I . I)$ \\
\hline Neutrophyl(x109/L) & 3.2 & 2.5 & 1.95 & 4.6 & 3.6 & 3 & 2.4 & 4.7 \\
\hline$\% 90 \mathrm{Cl}$ & $(1.7-6.1)$ & $(1.0-5.8)$ & $(0.9-4.2)$ & $(2.5-7.4)$ & $(1.7-7.5)$ & $(1.4-6.5)$ & $(1.3-4.2)$ & $(2.7-7.9)$ \\
\hline Lymphocyte(x109/L) & 1.7 & 1.9 & 1.8 & 2.3 & 1.8 & 2 & 2 & 2.2 \\
\hline$\% 90 \mathrm{Cl}$ & $(1.0-2.9)$ & $(1.0-3.6)$ & $(1.0-3.2)$ & $(1.4-2.5)$ & $(1.0-3.5)$ & $(1.2-3.4)$ & $(I . I-3.6)$ & $(1.4-3.4)$ \\
\hline Monocyte(x109/L) & 0.34 & 0.33 & 0.29 & 0.6 & 0.3 & 0.31 & 0.28 & 0.53 \\
\hline$\% 90 \mathrm{Cl}$ & $(0.18-0.62)$ & $(0.18-0.52)$ & $(0.15-0.58)$ & $(0.3-I . I)$ & $(0.14-0.61)$ & $(0.16-0.59)$ & $(0.15-0.39)$ & $(0.3-0.8)$ \\
\hline Eosinophil(x $\left.10^{9} / \mathrm{L}\right)$ & 0.12 & 0.13 & 0.12 & 0.19 & 0.13 & 0.1 & 0.1 & 0.15 \\
\hline$\% 90 \mathrm{Cl}$ & $(0.03-0.48)$ & $(0.03-0.58)$ & $(0.02-0.79)$ & $(0-0.5)$ & $(0.04-0.44)$ & $(0.03-0.33)$ & $(0.02-0.4 I)$ & $(0-0.4)$ \\
\hline $\operatorname{PLT}\left(x \mid 0^{9} / L\right)$ & 218 & 196 & 183 & 232 & 246 & 236 & 207 & 254 \\
\hline$\% 90 \mathrm{Cl}$ & $(\mid 43-332)$ & $(|22-3| 3)$ & $(115-290)$ & $(|63-32|)$ & $(169-358)$ & $(\mid 49-374)$ & $(125-342)$ & $(|7|-346)$ \\
\hline
\end{tabular}

$\mathrm{Cl}$ : Confidence interval 
Table 7 RBC-Hemoglobin-Hematocrit-MCV-MCHC and percentile intervals(\%5-95) in different ethnicities

\begin{tabular}{|c|c|c|c|c|c|c|c|c|c|c|c|c|}
\hline \multirow[b]{2}{*}{$\begin{array}{l}\text { CBC } \\
\text { Reference } \\
\text { Intervals }\end{array}$} & \multicolumn{6}{|l|}{ Men } & \multicolumn{6}{|c|}{ Women } \\
\hline & $\begin{array}{l}\text { Ameri- } \\
\text { can }\end{array}$ & $\begin{array}{l}\text { Results } \\
\text { of our } \\
\text { study }\end{array}$ & African & $\begin{array}{l}\text { South } \\
\text { Africa }\end{array}$ & Hispanic & Asian & $\begin{array}{l}\text { Ame- } \\
\text { rican }\end{array}$ & $\begin{array}{l}\text { Re- } \\
\text { sults } \\
\text { of our } \\
\text { study }\end{array}$ & $\begin{array}{l}\text { Afri- } \\
\text { can } \\
\text { central }\end{array}$ & $\begin{array}{l}\text { South } \\
\text { Afri- } \\
\text { ca }\end{array}$ & $\begin{array}{l}\text { Hispa- } \\
\text { nic }\end{array}$ & Asian \\
\hline number & NA & $(n=35 I)$ & NA & NA & $(n=3 \mid 6)$ & $(n=254)$ & NA & $(n=363)$ & NA & NA & $(n=276)$ & $(n=227)$ \\
\hline $\begin{array}{l}\text { RBC (SI) } \\
\text { Min \%90 Cl }\end{array}$ & $4.5-5.9$ & $5,02 \pm 0,4$ & $4.5-6.1$ & $3.2-5.8$ & 4.14-5.68 & $4.06-5.97$ & $4.0-5.2$ & $\begin{array}{l}4,41 \pm \\
0,36\end{array}$ & $\begin{array}{l}3.42- \\
5.44\end{array}$ & $\begin{array}{l}3.0- \\
5.3\end{array}$ & $\begin{array}{l}3.71- \\
5.06\end{array}$ & $\begin{array}{l}3.66- \\
5.05\end{array}$ \\
\hline $\begin{array}{l}\text { Hemoglobin } \\
\left(\times 10^{9} / \mathrm{L}\right) \text { Min } \\
\% 90 \mathrm{Cl}\end{array}$ & $\begin{array}{l}13.5- \\
17.5\end{array}$ & $15,39 \pm 1$ & $\begin{array}{l}12.3- \\
17.3\end{array}$ & $\begin{array}{l}10.3- \\
16.7\end{array}$ & $13.5-17.0$ & $12.2-16.9$ & $\begin{array}{l}(12.0- \\
16.0)\end{array}$ & $\begin{array}{l}13,26 \\
\pm 1\end{array}$ & $\begin{array}{l}9.1- \\
14.9\end{array}$ & $\begin{array}{l}9.0- \\
15.2\end{array}$ & $\begin{array}{l}10.2- \\
14.8\end{array}$ & $\begin{array}{l}10.5- \\
14.9\end{array}$ \\
\hline $\begin{array}{l}\text { Hematocrit } \\
\% \% 90 \mathrm{Cl}\end{array}$ & $4 I-53$ & $44,69 \pm 3,2$ & $39-52$ & $31-52.5$ & $38.8-49.5$ & $36.7-49.4$ & $36-46$ & $\begin{array}{l}38,82 \pm \\
3,08\end{array}$ & $28-44$ & $\begin{array}{l}27.3- \\
47.2\end{array}$ & $\begin{array}{l}31.0- \\
44.1\end{array}$ & $\begin{array}{l}32.2- \\
43.8\end{array}$ \\
\hline $\begin{array}{l}\text { MCV fL Min } \\
\% 90 \mathrm{Cl}\end{array}$ & $80-100$ & $89, I \pm 4,88$ & NA & NA & $82.3-98.4$ & 69.9-99.8 & $80-100$ & $\begin{array}{l}88,2 \pm \\
4,92\end{array}$ & NA & NA & I.7-7.5 & $1.4-6.5$ \\
\hline $\begin{array}{l}\text { MCHC g/dL } \\
\text { Min } \% 90 \mathrm{Cl}\end{array}$ & NA & $\begin{array}{l}34,4 \\
\pm 1,06\end{array}$ & NA & NA & $32.4-35.8$ & $31.8-36.0$ & NA & $\begin{array}{l}34,1 \pm \\
0,92\end{array}$ & NA & NA & $\begin{array}{l}32.3- \\
35.7\end{array}$ & $\begin{array}{l}32.3- \\
35.8\end{array}$ \\
\hline
\end{tabular}

$\mathrm{Cl}$ : Confidence interval, NA: Not Available

\section{Ethical approval}

It is received from the Ethics Committee of the Manisa Celal Bayar Univercity in Manisa/Turkey. All subjects signed an informed consent and the study was conducted in accordance to the principles of the Declaration of Helsinki.

\section{Declaration of authorship}

EAK, ÜE designed the study. EAK, ÜE and CO performed data acquisition. EAK, $\mathrm{CO}$ analyzed and interpreted the data. EAK and UE drafted the manuscript. All co-authors critically reviewed the manuscript and gave their final approval of the version of the manuscript to be published.

\section{Competing interests}

The author declares that there are no conflicts of interest.

\section{References}

1. Tsang CW, Lazarus R, Smith W, et al. Hematological indices in an older population sample: Derivation of healthy reference values. Clin Chem. 1998;44(1):96-101.

2. Bain BJ. Ethnic and sex differences in the total and differential white cell count and platelet count. J Clin Pathol. 1996;49(8):664-666.

3. Saxena S, Wong ET. Heterogeneity of common hematologic parameters among racial, ethnic, and gender subgroups. Arch Pathol Lab Med. 1990;114(7):715-719.

4. Qiao R, Yang S, Yao B, et al. Complete blood count reference intervals and age-and sex related trends of North China Han population. Clin Chem Lab Med. 2014;52(7):1025-1032.

5. Ji C, Su Y, Zhang C, et al. Reference intervals for hemoglobin and ageand gender-related trends in the population of South West China. Clin Lab. 2015;61(12):1831-1836.

6. Terzioğlu M, Savcı D, Özek M. Türklerde normal hematolojik değerler. İstanbul Üniversitesi Tıp Fakültesi Dergisi. 1953;16:193-207.

7. Başak M, Gül S, Küçükardalı Y. Türkiye'de Hemogram Değerleri ile İlgili Randomize Refarans Değer Çalışması. Türk Hematoloji-Onkoloji Dergisi. 1998;8:2;69-72.
8. Kaya H, Kiki İ, Akarsu E, et al. Hematological values of healthy adult population living at moderate altitude (1869 m, Erzurum, Turkey). Turk $J$ Haematol. 2000;17(3):123-128.

9. Dilek I, Erkoç R, Sayarlığlu M, et al. Van İli Merkez ve Kırsal Kesimde Yaşayan Sağlıklı Erişkin Bireylerde Hemogram ve Ferritin Düzeyleri. Van Medical Journal. 2002;9:(2):52-55.

10. Yılmaz SF, Erdal S, Bakıcı Z, et al. Investigation of the normal values of some haematological parameters of the adults living in the central region of Sivas. Erciyes Med J. 2003;25:1-10.

11. Tamer ŞA, Çavuşoglu H, Sivas A. 16-25 yas grubu sağlıklı kişilerde kan parametreleri ve kan biyokimyası değerleri. İstanbul Tip Fakültesi Mecmuas1. 1991;54:223-230.

12. Castro OL, Haddy TB, Rana SR. Age and sex related blood cell values in healthy black Americans. Public Health Rep. 1987;102(2):232-237.

13. Sirdah MM, Tarazi IS, El Jeadi H, et al. Normal blood cell reference values of healthy adults in Gaza strip-Palestine. J Clin Lab Anal. 2008;22(5):353-361.

14. Roshan TM, Rosline H, Ahmed SA, et al. Hematological referance values of healty Malaysian population. Int J Lab Hematol. 2009;31(5):505-512.

15. Tuncer I, Ercan M, Akdeniz H. A regional study on the effects of altitude on hematological parameters in Van City of Turkey. East $J$ Med. 1996;2:124-126.

16. Tikly M, Blumsohn D, Solomons HD, et al. Normal haematological reference values in the adult black population of the Witwatersrand. $S$ Afr Med J. 1987;72(2):135-136.

17. Kelly A, Munan L. Haematologic profile on natural populations; red cell parameters. Br J Haematol. 1977 Jan;35(1):153-60.

18. Kueviakoe IM, Segbena AY, Jouault H, et al. Hematological Reference Values for Healthy Adults in Togo. Int Sch Res Notices. 2011;2011:1-5.

19. Rana SR, Castro OL, Haddy TB. Leukocyte counts in 7739 healthy black persons, effects of age and sex. Ann Clin Lab Sci. 1985;15(1):51-54.

20. Wu X, Zhao M, Pan B, et al. Complete Blood Count Reference Intervals for Healthy Han Chinese Adults. PLoS One. 2015;10(3):e0119669. 